\title{
RING SEA ANEMONES, AN OVERVIEW (CNIDARIA, ANTHOZOA, ACTINIARIA)
}

\author{
O. Ocaña ${ }^{1}$, J. C. den $\operatorname{Hartog}^{2}$ \& L. P. van Ofwegen ${ }^{3}$
}

\begin{abstract}
The present observations represent a new record of species of Actiniaria that are able to attach to a gorgonian branch by surrounding it with a solid piece of tissue junction and a significant reduction of the coelenteron. Ring sea anemones are provisionally placed in the Actinostolidae. They seem to be more common at depths between 85 and $1500 \mathrm{~m}$., and according to our observations they are specialized to exclusively colonize on some species of gorgonians or pennatulaceans. Parasitism best describes the relationship between ring sea anemones and their hosts. We recognize five different species of ring sea anemones, one described by Hiles (1899) as Peronanthus verrucellae, and the others named by us provisionally as Peronanthus sp1, sp2, sp3 \& sp4. The strategy displayed by ring sea anemones has several advantages, such as placement economy (see above), a better attachment against any current action, exploitation of food resources inaccessible to most other Actiniarians, and it allows them avoidance of habitat competition. The impossibility to colonize any other substrate but a certain group of gorgonians and a reduction of the gastric cavity are the main disadvantages detected in the ring sea anemones' way of life. Apparently, this group of sea anemones is widespread through the Pacific Ocean.
\end{abstract}

Keywords: Actiniaria, Novel attachment strategy, Parasitism, Association with gorgonians, IndoPacific.

\section{RESUMEN}

\section{Anémonas anillo, una visión general (Cnidaria, Anthozoa, Actiniaria)}

Un nuevo grupo de especies de actiniarios que desarrollan un nuevo sistema para afianzarse alrededor de los ejes de gorgonias y pennatuláceos es estudiado por nosotros en el presente trabajo. Se trata de un anillo de tejido que rodea los ejes y queda perfectamente sellado por medio de uniones del tejido produciendo una reducción del celenterón. Anémonas anillo es como las hemos denominado y provisionalmente han sido incluidas dentro de la familia Actinostolidae. Parece que son comunes en profundidades comprendidas entre los 85 y los 1500 metros, colonizando solamente determinadas especies de gorgonias y de pennatuláceos. El parasitismo es la relación que mejor describe lo que acontece entre las anémonas y los octocorales que la portan. Hay, al menos, cinco especies diferentes de anémonas anillo, la primera fue descrita por Hiles (1899) como Peronanthus verrucellae, las otras especies las denominamos provisionalmente como Peronanthus sp1, sp2, sp3 y sp4. El modo de vida de estas especies presenta ciertas ventajas como son: una reducción del espacio para asentarse, una mejor fijación frente a fenómenos de corriente, la capacidad para explotar recursos inaccesibles a la mayoría de los actiniarios y por último la falta de competencia con otras especies por el hábitat. La imposibilidad de colonizar otros sustratos y la reducción de la cavidad gástrica son las principales desventajas que presenta este modo de vida exhibido por las anémonas anillo. Aparentemente este grupo de anémonas está ampliamente distribuido en el Indo-Pacífico.

Palabras clave: Actiniaria, nueva estrategia de fijación, Parasitismo, Asociación con gorgonias, Indopacífico.

O. Ocaña, Instituto de Estudios Ceutíes (CECEL-CSIC), Paseo del Revellín, 30, 51001 Ceuta (North Africa), Spain. lebruni@telefonica.net

J. C. den Hartog, National Museum of Natural History, Postbus 9517, 2300 RA Leiden, The Netherlands. Deceased (1942-2000). L. P. van Ofwegen, National Museum of Natural History, Postbus 9517, 2300 RA Leiden, The Netherlands. ofwegen@naturalis.nnm.nl 


\section{Introduction}

Isa Hiles (1899) was the first to describe a species of ring sea anemones (RSA). She studied material collected by A. Willey in New Britain (Papua New Guinea) coasts. The author described a new genus and species, Peronanthus verrucellae, attached to a gorgonian identified as Verrucella guadalupensis Duchassaing \& Michelotti, 1860, and placed it into the family Amphianthidae. Hiles' description remained unnoticed by actinian workers as it was very brief and included in a paper chiefly dealing with octocorals. Carlgren's (1936) Stephanauge annularis, living on pennatularians, was subsequently recognized as another species of ring sea anemone (see Fautin, 2003).

During the last two decades several species of ring sea anemones have been recorded in different areas of the Pacific Ocean, from Japan to New Zealand, on different bottoms and depths, 30-1500. Ring sea anemones are remarkable because of their particular attachment to gorgonians. They show a high degree of morphological transformation, resulting in a considerable differentiation between the pedal disc system and the rest of the body. The ring attachment is unknown in any other actinians that live as epibionths on anthozoan (e.g., Hormathiidae). In addition, RSA may be parasites of their octocorals hosts.

Because of the presence of a mesogloeal sphincter and the absence of acontia we provisionally include RSA in the family Actinostolidae, and place all our material in the genus Peronanthus Hiles, 1899. Further studies are needed to clarify the taxonomic status of the group of ring sea anemones.

\section{Material and methods}

MATERIAL EXAMINED.- NZOI Stn P941, New Zealand, $41^{\circ} 15.2^{\prime} \mathrm{S}, 167^{\circ} 07.2^{\prime} \mathrm{E}, 1457-1463 \mathrm{~m}$, many specimens on Keratoisis sp., 23/04/1980; MONZ, New Zealand, 3554.50'S $169^{\circ} 59.18^{\prime} \mathrm{E}, 950 \mathrm{~m}$, five specimens on Anthothela sp., 7/1994, F.V. Petersen leg.; DC 176, NW Reunion Island, $21^{\circ} 01.7^{\prime}$ S, 55 10.6'E, nine specimens on Ellisella sp., $165-195 \mathrm{~m}$, 8/9/1982, H. Zibrowius leg.; WMNH OCT-1001, Japan, $33^{\circ} 56^{\prime} \mathrm{N}, 135^{\circ} 7^{\prime} \mathrm{E}, 30-50 \mathrm{~m}$, many specimens on branch of Verrucella sp., 26/4/2000.

Part of the material studied here in the present work was collected by trawling in the New Zealand EEZ. One of the samples belongs to NIWA (National Institute of Water and Atmospheric Research), the other to MONZ (National Museum of Natural History of New Zealand). Material from
Reunion Island, was dredged during the "Marion Dufresne" cruise MD32 in 1982. Additional material came from the Japan Sea, and was collected in the Wakayama region by Dr. Y. Imahara from the Wakayama Museum of Natural History.

Some specimens were fixed in $8-10 \%$ formaldehyde before storing in $70 \%$ ethanol. Others were fixed and preserved in ethanol the usual liquid used for gorgonians. The general morphology, anatomy and other observations related to the positioning of the anemones on the gorgonians were studied by means of a stereo dissecting microscope. Histological details were examined and studied with a light microscope.

\section{Results}

MORPHOLOGICAL CHANGES AND DIFFERENCES

As a consequence of the particular attachment some significant changes took place in the anatomy of these species. Instead of the usual pedal disc, there is a "pedal ring" formed by the pedal disc tissue and part of the column. Surrounding the gorgonian branch solidly (Figs. 1 and 2), is the most striking morphological change detected in RSA that distinguishes this group from all other Actiniaria. As a consequence of this peculiar morphology, most of the tissue is concentrated in a shortened column. Breaking the pedal ring is necessary to detach RSA from the gorgonian branch.

All ring sea anemones share this type of attachment to the gorgonian branch. However, there are enough in shape differences to distinguish two morphological groups of RSA. The first group comprises part of the material from New Zealand (NZOI Stn P941; Peronanthus sp1) (Fig. 3), the material from Reunion Island (Peronanthus sp2) (Fig. 4), Papua New Guinea Peronanthus verrucellae (Hiles, 1899), and from Japan (Peronanthus sp3) (Fig. 5). Stephanauge annularis (Carlgren, 1936) also seems to belong here. The small RSA of this group show strong dimorphism between the upper part (concentration of oral disc, tentacles, pharynx and the mesenteries) and the pedal ring. These forms present inconspicuous external scars on the tissue junction, observable only by binocular microscope, in some specimens hardly visible at all. So far, this group of ring sea anemones has been recorded only on gorgonians with smooth branch surface.

The other morphological group is represented by the remaining material from New Zealand (Peronanthus sp4) (Fig. 6). These are rather big sea 

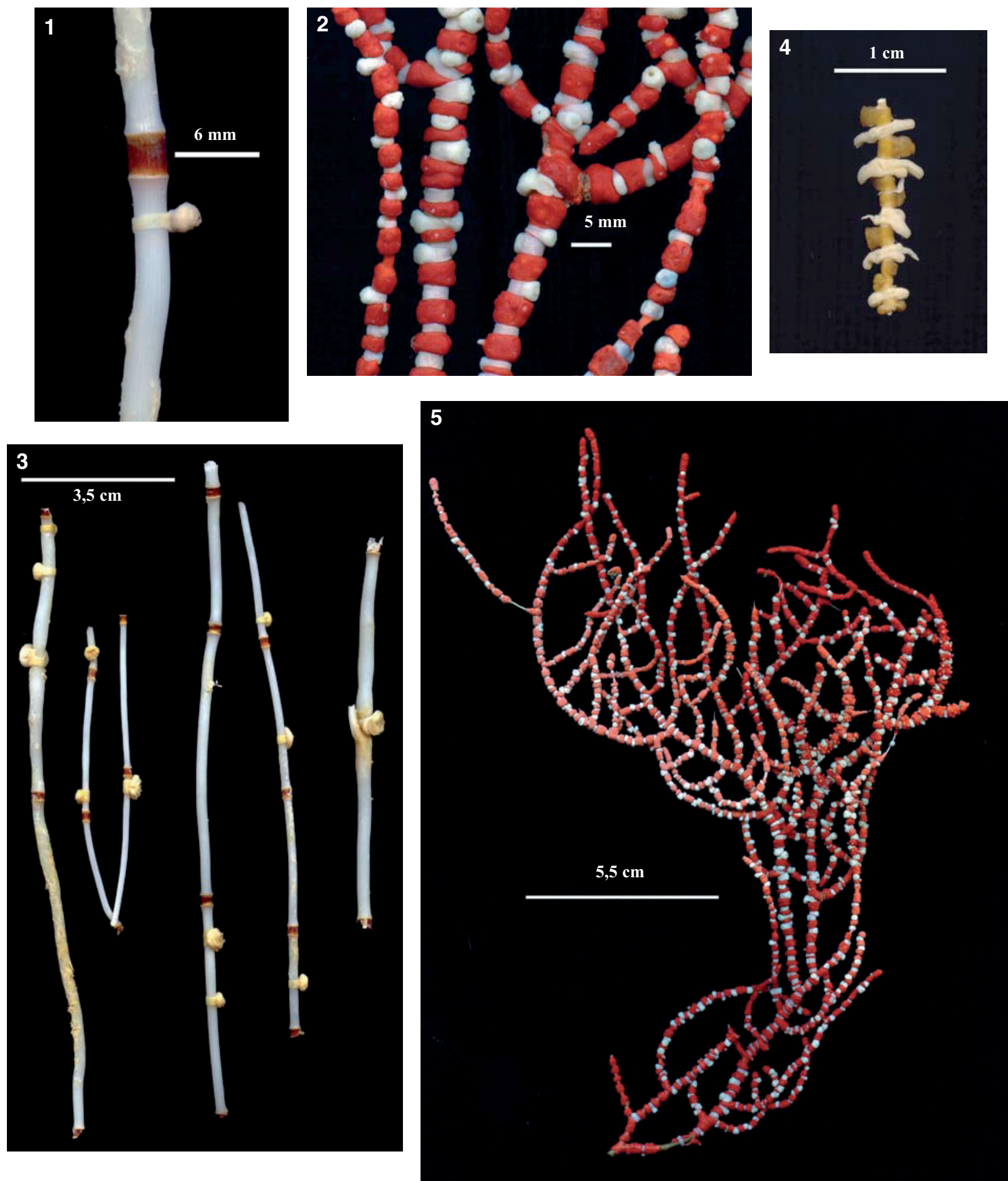

Figs. 1-5.- 1) Peronanthus sp1 showing the pedal ring. 2) Peronanthus sp3 showing the pedal ring. 3) Peronanthus sp1 general view. 4) Peronanthus sp2 general view of the colony fragment. 5) Peronanthus sp3 general view of the colony.

Figs. 1-5.- Peronanthus sp1 con su anillo pedal. 2) Peronanthus sp3 con su anillo pedal. 3) Peronanthus sp1, visión general de la especie. 4) Peronanthus sp2, visión general de un fragmento de la colonia. 5) Peronanthus sp3, visión general de la colonia. 
anemones with prominent tubercles and a thick mesogloea that shows conspicuous external scars on the tissue junction (Fig. 7). In addition, a thick periderm or cuticle occurs in the area that surrounds the gorgonian branch, isolating the anemone from the abrasive gorgonian surface where it was noticed. More than one pedal ring can occur in the same specimen.

In both groups the coelenteron is extremely reduced along the pedal ring and mesenteries were not detected. Apparently RSA has no limbus, a thin periderm covers some areas in contact with the gorgonian branch. It seems to be more conspicuous in some areas than others. A reticular mesogloeal structure was observed along the column of the second group (Fig. 8), consistent with the sponginess observed in the mesogloea. All species analysed by us only have a single siphonoglyph (Fig. 9).

\section{Hosts, Distribution AND Habitats}

Gorgonians and pennatulaceans are the only substrate known for ring sea anemones. Ring sea anemones live on at least four different gorgonian species belonging to four different genera, Ellisella Gray, 1858, Verrucella Milne Edwards \& Haime, 1857 (both family Ellisellidae), Anthothela Verrill,
1879 (family Anthothelidae), and Keratoisis Wright, 1869 (family Isididae). At present, none of them could be identified with complete certainty to species level (see Table 1).

Hiles (1899) reported Peronanthus verrucellae as living on Verrucella guadalupensis Duchassaing \& Michelotti, 1860. Kükenthal (1924) and Toeplitz (1929) referred Hiles' " $V$. guadalupensis" to the Indo-Pacific Nicella dichotoma (Gray, 1860), the holotype of which species has been redescribed by Bayer \& Grasshoff (1994). Undoubtedly, Hiles' identification was wrong; since Nicella guadalupensis (Duchassaing \& Michelotti, 1860) is a typically Caribbean species (see Bayer, 1961). Another argument for considering the identification as erroneous is that Bayer \& Grasshoff mentioned few or no anastomoses for $N$. dichotoma, whereas Hiles mentioned anastomoses to occur fairly frequently in her specimen. Because of the anastomoses mentioned by Hiles it is possible that her specimen actually was a Verrucella, but re-examination of the material would be needed to ascertain this.

The fragmentary material of Ellisella sp. from Reunion Island did not allow identification to species level. The same applied to Keratoisis sp. from New Zealand.

Table 1.- Comparison of several characters of ring sea anemones.

Tabla 1.- Comparación de algunas características de las anémonas anillo.

\begin{tabular}{|c|c|c|c|c|c|}
\hline $\begin{array}{l}\text { Species / } \\
\text { Characteristics }\end{array}$ & $\begin{array}{l}\text { Peronanthus } \\
\text { sp1 }\end{array}$ & $\begin{array}{l}\text { Peronanthus } \\
\text { sp2 }\end{array}$ & $\begin{array}{l}\text { Peronanthus } \\
\text { sp3 }\end{array}$ & $\begin{array}{l}\text { Peronanthus } \\
\text { sp4 }\end{array}$ & $\begin{array}{c}\text { Stephanauge } \\
\text { annularis }\end{array}$ \\
\hline Host substrates & Keratoisis sp. & Ellisella $\mathrm{sp}$. & Verrucella $\mathrm{sp}$. & Anthothela sp. & Halipteris californica \\
\hline Geographical distribution & New Zealand & Reunion Island & Japan & New Zealand & California \\
\hline Depths & $1457-1463 \mathrm{~m}$ & $165-195 \mathrm{~m}$ & $30-50 \mathrm{~m}$ & $950 \mathrm{~m}$ & $128 \mathrm{~m}$ \\
\hline Size & $\begin{array}{l}\text { 3-7 mm long } x \\
4-10 \mathrm{~mm} \text { wide }\end{array}$ & $\begin{array}{l}1.5-4 \mathrm{~mm} \text { long } \mathrm{x} \\
1-3 \mathrm{~mm} \text { wide }\end{array}$ & $\begin{array}{l}\text { 3-6 mm long } x \\
2-5 \mathrm{~mm} \text { wide }\end{array}$ & $\begin{array}{l}\text { 15-25 mm long } x \\
13-22 \mathrm{~mm} \text { wide }\end{array}$ & $\begin{array}{l}1.5 \mathrm{~cm} \text { long } \mathrm{x} \\
1 \mathrm{~cm} \text { wide }\end{array}$ \\
\hline Colour & whitish & brownish & bright white & whitish & brownish \\
\hline Morphological Group & I & I & $\mathrm{I}$ & II & $\mathrm{I} ?$ \\
\hline Gonads detected & no & no & no & ova noticed & sperm noticed? \\
\hline Asexual multiplication observed & yes & yes & yes & no & $?$ \\
\hline Position on host & between polyps & between polyps & between and on polyps & between and on polyps & on polyps \\
\hline Movements & $\begin{array}{l}\text { elongate the } \\
\text { pedal ring }\end{array}$ & $?$ & $\begin{array}{l}\text { breaking the } \\
\text { pedal ring }\end{array}$ & $\begin{array}{l}\text { breaking the } \\
\text { pedal ring? }\end{array}$ & $?$ \\
\hline Distinctive characters & $\begin{array}{l}\text { small to medium } \\
\text { size polyps, capitulum } \\
\text { always wider than } \\
\text { the pedal ring. }\end{array}$ & $\begin{array}{l}\text { small size polyps, } \\
\text { capitulum as wide } \\
\text { as the pedal ring. }\end{array}$ & $\begin{array}{l}\text { small size polyps, } \\
\text { capitulum slightly wider } \\
\text { than the pedal ring. }\end{array}$ & $\begin{array}{l}\text { capitulum with tubercles, } \\
\text { big size polyps. }\end{array}$ & $\begin{array}{l}\text { medium size } \\
\text { polyps, presence } \\
\text { of cinclides } \\
\text { on tubercles. }\end{array}$ \\
\hline
\end{tabular}



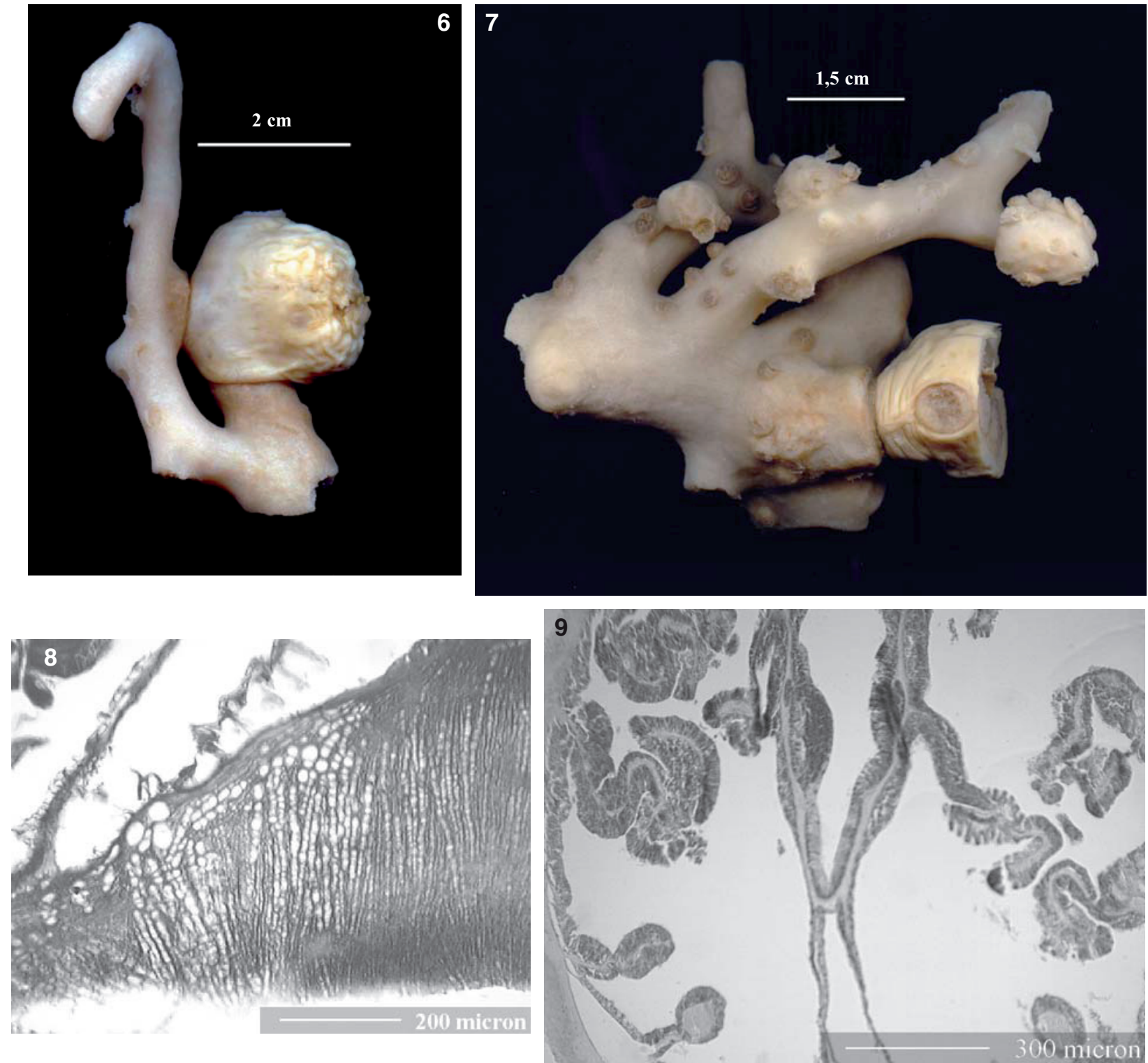

Figs 6-9.- 6) Peronanthus sp4 general view. 7) Peronanthus sp4 showing conspicuous junction scars. 8) Reticular structure of the mesogloea of Peronanthus sp4. 9) Siphonoglyph of Peronanthus sp1.

Figs 6-9.- 6) Peronanthus sp4, visión general de la especie. 7) Peronanthus sp4 mostrando cicatrices muy conspicuas. 8) Estructura reticular de la mesoglea de la especie Peronanthus sp4. 9) Sifonoglifo de un ejemplar de la especie Peronanthus sp1.

The specimen from Japan clearly belongs to the genus Verrucella. However, because of the inadequate descriptions of Japanese Ellisellids available no attempt has been made to identify the specimen to species level.

We identified the Anthothela specimen from New Zealand as A. cf. vickersi (Benham, 1928).
Originally, that species was found off North Island, not that far from the location of the present specimen. Unfortunately, Benham provided only some schematic drawings of the sclerites so the identity of the present material remains uncertain. It can only be obtained by re-examination of type material of $A$. vickersi. 
To conclude, ring sea anemones have been found on four different gorgonian species belonging to four genera, Ellisella Gray, 1858 and Verrucella Milne Edwards \& Haime, 1857 (both family Ellisellidae), Anthothela Verrill, 1879 (family Anthothelidae), and Keratoisis Wright, 1869 (family Isididae).

In addition, Stephanauge annularis (Carlgren, 1936), has been recorded as living on the pennatulacean Halipteris californica (Moroff, 1902).

Gorgonians and pennatulaceans are the only substrate known for ring sea anemones. Keratoisis sp and $A$. cf. vickersi were recorded from 950 to 1463 meters deep. These two species are from muddy bottoms where the environmental conditions make it difficult to find a hard substrate to grow.

Ellisella species are known from the Mediterranean, Atlantic, and Indo-Pacific, live in both tropical and temperate waters, but rarely occur above $10 \mathrm{~m}$ depth. The genus Verrucella occurs in the Indo-Pacific, and is also rare above $10 \mathrm{~m}$ depth.

\section{REPRODUCTION}

We found traces of asexual reproduction, mostly longitudinal fission, in three of the four species of RSA studied here, an expected adaptation to colonize gorgonian branches.

Probably sexual reproduction resulting in free larvae stages is used for dispersion of the species to other colonies. In fact, both reproduction pathways could be used at the same time, for reaching different colonies and for reaching different areas of the same colony. In Peronanthus sp4 ova were found.

\section{Discussion}

\section{TAXONOMICAL REMARKS}

Actinostolidae is the most appropriate family to place RSA provisionally, and it was chosen because of the combination of retractors character (diffuse and weak) and the regular pattern of tentacles arrangement (see Carlgren, 1949). The peculiar tentacles arrangement described in Exocoelactiidae and the presence of strong and restricted retractors muscles in Isanthidae place these families far from RSA. Perhaps the morphological changes found in such species may justify the erection of a new family (Ocaña y den Hartog, in prep.).

\section{A SOPHISTICATED ATTACHMENT STRUCTURE FOR SOFT ANTHOZOA}

Ring anemones are unique in having totally fused into one piece around the substrate axis. Breaking the pedal ring is the only means to remo- ve the anemone from the host (unless you consider cutting the host's axis). This fact is a remarkable phenomenon not recorded for any other Actiniaria before. Some other actinians (mainly of the family Hormathiidae) also attach efficiently to the branches of gorgonians, but all of these manage this in different ways and always maintain the standard pedal disc structure. Although sometimes those pedal discs are twisted around the branch or other substrate the pedal disc structure is preserved and there is no trace of tissue fusion. Examples reported in the literature: Adamsia carciniopados (Otto, 1823) by Ocaña (1994), Actinoscyphia saginata by Carlgren (1934), and Amphianthus impeditus by Gravier (1922).

Actiniaria display other strategies in order to attach to a branch. These include the pedal disc clasping the branch or an extended pedal disc surrounding the branch in part or totally. In the latter case both sides of the pedal disc may encounter each other at the limbus but there is no tissue junction. Although the "conventional" pedal disc is obviously less efficient in attaching to a branch than a pedal ring, there are a number of sea anemones able to live attached to gorgonians and hydroids using these simple means. Generally, the species in question also occur on other substrates as is the case for Anphianthus dorhnii (von Koch, 1878) and species of genera Nemanthus or Actinostola.

The attachment strategy of the ring sea anemones gives them certain advantages, but also some disadvantages.

\section{Advantages}

- Placement economy: pedal ring attachment needs fewer settling places.

- Better attachment by having totally fused into one piece around the substrate axis.

- To exploit food resources in habitats which are inaccessible to most of the Actiniaria.

- It avoids habitat competition with other Actiniaria with pedal discs and living on "conventional" substrates.

- Pedal ring contributes to reduce the live parts of the gorgonians keeping them at a distance.

\section{Disadvantages}

- There seems to be a strong relationship between the ring sea anemones and their host's limited settling places. So the presence of gorgonian species is a limiting factor for ring sea anemones growing. 

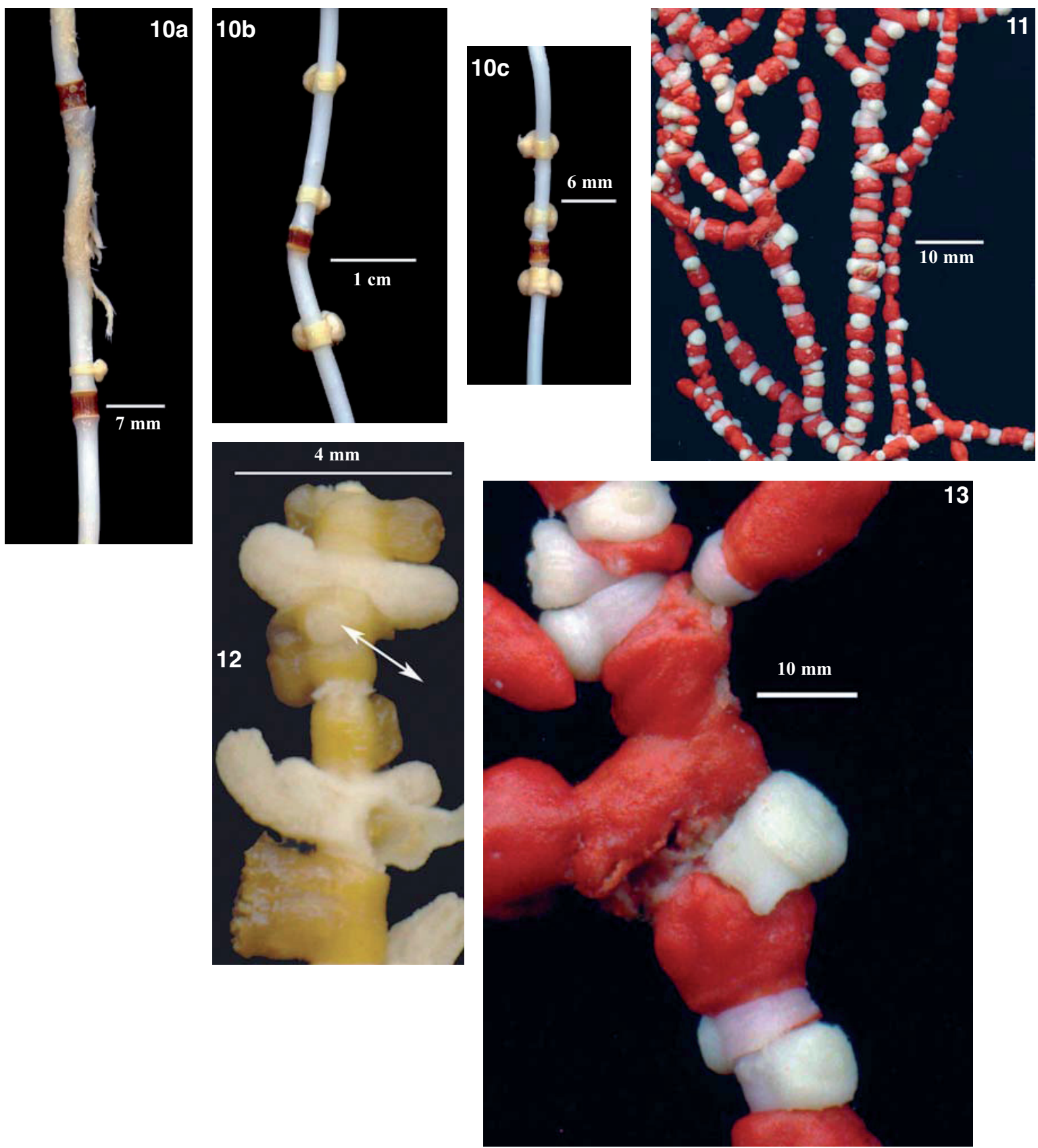

Figs. 10-13.- 10a) Peronanthus sp1 close to long size polyps; 10b) group of Peronanthus sp1; 10c) group of Peronanthus sp1. 11) Peronanthus sp3 growing on polyps and coenenchyme. 12) Synchronicity between the gorgonian budding and the longitudinal fissions of Peronanthus sp2. 13) Peronanthus sp3 braking the pedal ring almost completely.

Figs. 10-13.- 10a) Peronanthus sp1 en las cercanías de grandes pólipos de la gorgonia; 10b) grupo de ejemplares de la especie Peronanthus sp1; 10c) grupo de ejemplares de la especie Peronanthus sp1. 11) Ejemplares de la especie Peronanthus sp3 instalados sobre los pólipos y el cenénquima de la gorgonia. 12) Sincronización detectada entre la formación de nuevos pólipos en la gorgonia y la reproducción asexual en la especie Peronanthus sp2. 13) Ejemplares de la especie Peronanthus sp3 con el anillo pedal casi completamente roto. 
- They are not able to colonize (or at least not in an efficient way) other substrates.

- The pedal ring system reduces the gastric cavity of the ring sea anemones.

\section{MOVEMENTS AND POSITIONING ON THE COLONY}

All the species here mentioned inhabit gorgonian branches; Peronanthus sp1 and Peronanthus sp2 have been found on gorgonians with large polyps where they are placed between the gorgonian polyps or on areas without polyps (Fig. 10a-c). On the two species of gorgonians with small polyps, the other RSA (Peronanthus sp3 and Peronanthus sp4) occur between and on the gorgonian polyps (Fig. 11).

Differences of asexual reproduction patterns have been detected supporting the idea of high specialization of species of Peronanthus in relation to their hosts. In Peronanthus sp2 (Reunion Island) we observed some synchronicity between the gorgonian polyp growth and the longitudinal fission of the sea anemone. The small sea anemones positioned themselves around the young polyp (Fig. 12). This may be considered as an advantage in order to obtain space along the gorgonian branch while avoiding the normally big polyps of this gorgonian species. In addition, using this process, the polyps of the gorgonians remain isolated between two anemones making it easy to eliminate them by lateral crushing (see nature of the association).

In the species from Japan we noticed that two fissions (if not more) may occur in the same specimen but no trace of synchronicity between gorgonian polyp growth and longitudinal fission was observed. The species is hosted by a species of Verrucella with small polyps, where the sea anemones may proceed differently in order to conquer space along the branch. Polyps of the sea anemones can move over the adjacent area after breaking partially (about half of its width) or totally (see Fig. 13) the pedal ring.

In Peronanthus sp1 from New Zealand (NZOI Stn. P941), examination of many sea anemones, did not show any trace of broken pedal ring. However, one atypically elongated pedal ring, exceeding the diameter of the gorgonian branch, was noticed (Fig. 14). This observation suggests that the species may move along the branch without breaking the pedal ring.

As a consequence of asexual multiplication several RSA can be positioned very close to each other, but in that case we observed them to have the oral disc directed on different planes; thereby avoiding interfering which each other (see Fig. 15).
In Peronanthus sp4 (from New Zealand MONZ), some widely separated specimens space out did not show any sign of asexual reproduction. RSA is able to form several pedal rings in the same specimen (see Fig. 22). As a consequence of this, Peronanthus sp4 can attach to several branches at the same time by forming two or three pedal rings in the same individual. Movement along the branches was not detected but presumably it occurs following breaking the pedal ring as in some specimens pedal rings were observed to be in the process of making junctions.

\section{NATURE OF THE ASSOCIATION}

We did not find any trace of gorgonian tissue in the coelenteron of Peronanthus sp1 and sp2 growing on Keratoisis and Ellisella. In these associations the RSA may only need a place on which to grow, displacing the gorgonian polyps. Certainly the dense settlement of the RSA specimens between the polyps of Keratoisis and Ellisella alters the coenenchyme connection in the gorgonian. This can be understood as damage to the host although there is no evidence of predation, or other tissue absorbing by Peronanthus spp. In the material from Reunion Island, the trend seems to be to isolate and eliminate the polyps actively, combination of asexual multiplication synchronicity and lateral crushing (see Fig. 16).

Clear damage was noticed in the species of Verrucella from Japan overgrown by Peronanthus sp3. This species successfully covers the gorgonian polyps and coenenchyme. The gorgonian polyps are well embedded in the coenenchyme, containing small sclerites. With strangling by the ring sea anemone, the amount of gorgonian coenenchyme diminishes, and this process varies along the branch creating areas more affected than others (see Fig. 17). This processes results in eliminating of the gorgonian polyps and coenenchyme, leaving the axis bare (see Fig. 18). In some areas there is an atypical concentration of gorgonian polyps between RSA (see Fig. 19).

The case of Peronanthus sp4 from New Zealand is especially interesting because of gorgonian sclerites observed inside the coelenteron of the RSA. However, predation could not be ascertained as the sclerites could have been introduced accidentally when the RSA was sectioned for study. In fact, the host species is rich in sclerites, and preying on gorgonians by sea anemones has rarely been observed (Riemann-Zürneck, 1998; Riemann-Zürneck \& Griffiths, 1999; Dayton et al., 1995). However, predation via absorption of 

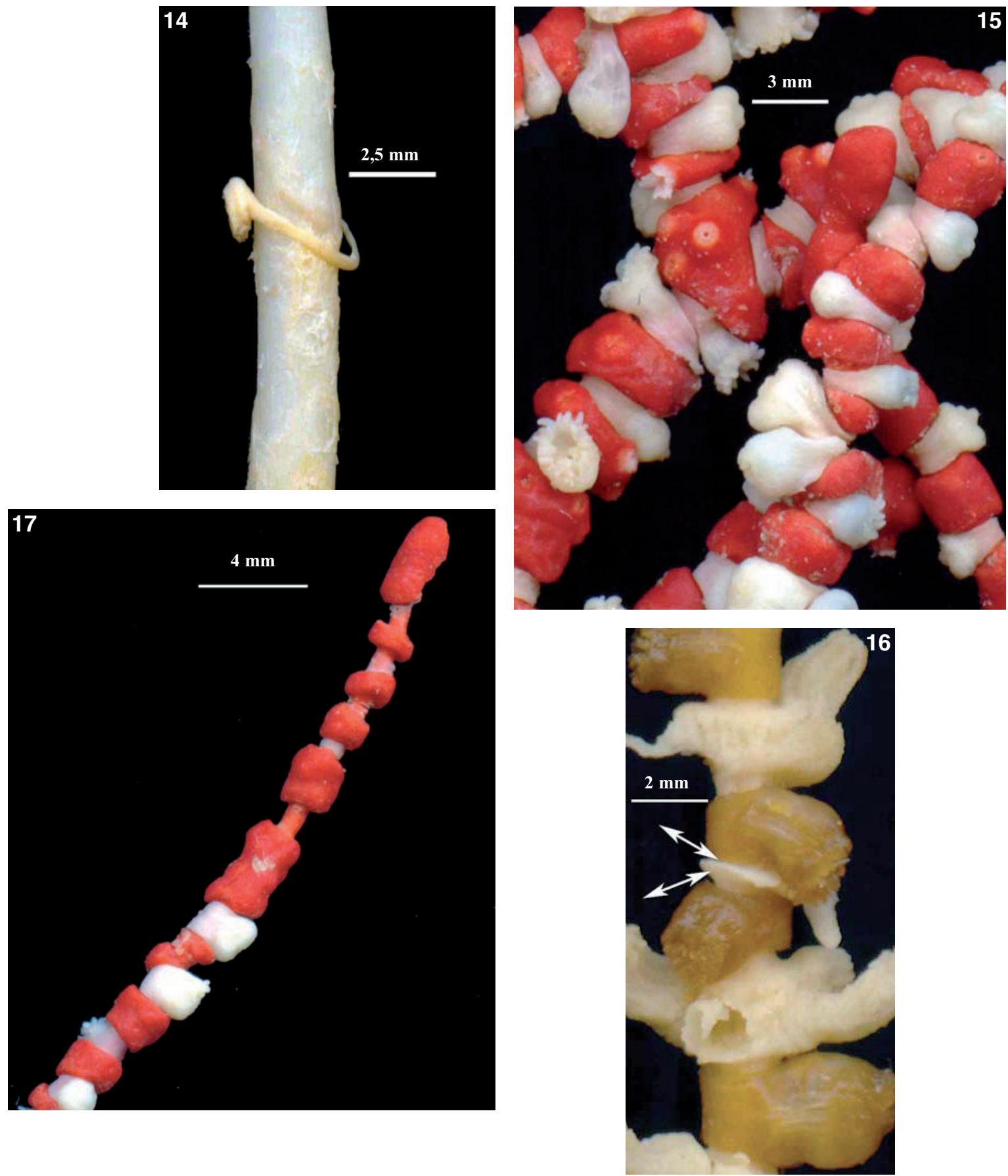

Figs. 14-17.- 14) Peronanthus sp1 with the elongate pedal ring exceeding widely the diameter of the gorgonian. 15) Peronanthus sp3 manage to accommodate the oral disc in different planes. 16) Lateral crushing is noticed in Peronanthus sp2. 17) Slimmed down areas caused by Peronanthus sp3.

Figs. 14-17.- 14) Peronanthus sp1 mostrando un alargamiento en el anillo pedal que sobrepasa ampliamente el diámetro del eje de la gorgonia que lo porta. 15) Ejemplares de la especie Peronanthus sp3 con los discos orales dispuestos en varios planos distintos. 16) Aplastamiento lateral de pólipos de la gorgonia provocados por ejemplares de la especie Peronanthus sp2. 17) Áreas adelgazadas por la acción de Peronanthus sp3. 

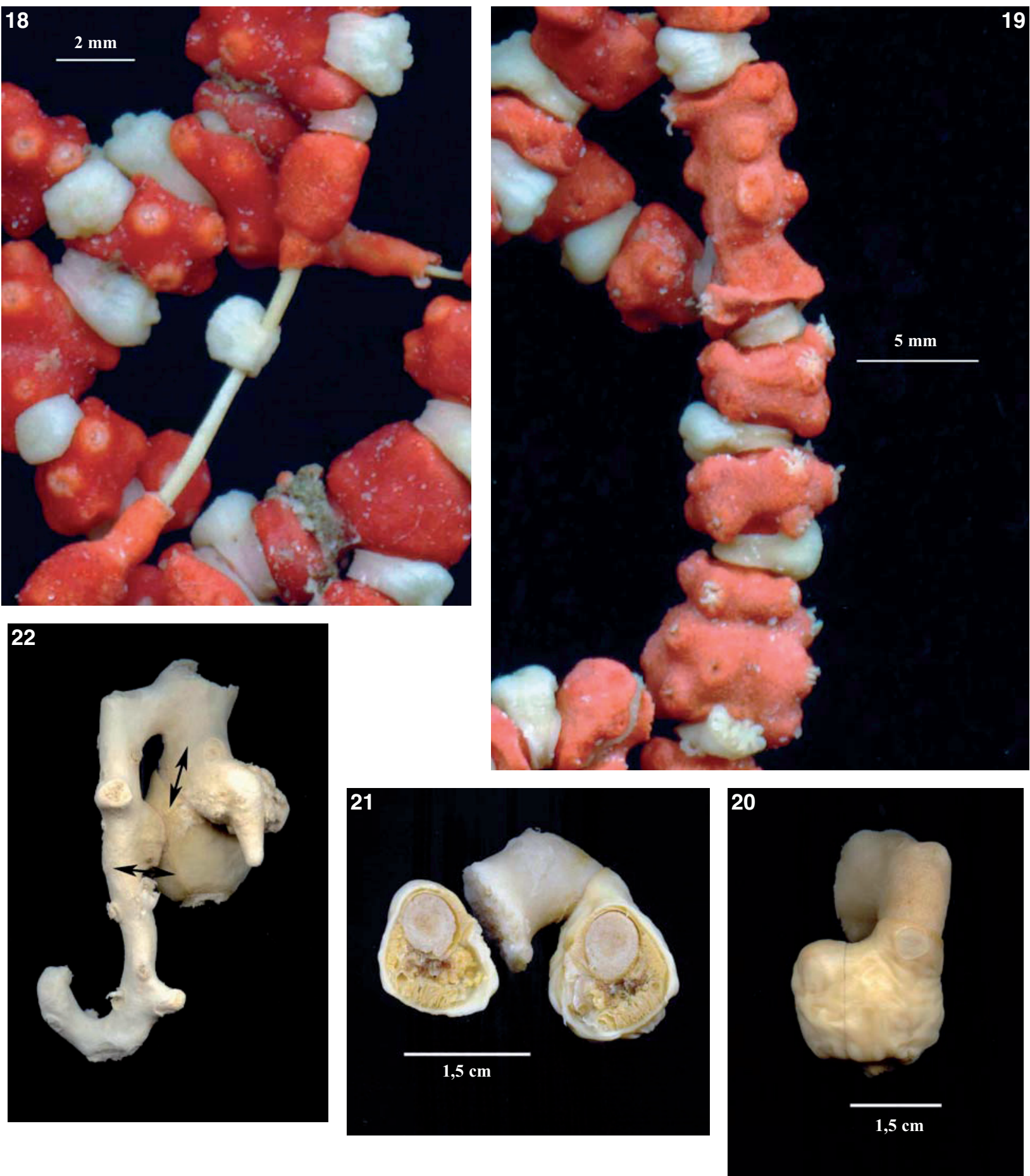

Figs. 18-22.- 18) Areas of the axis without coenenchyme in Peronanthus sp3. 19) Atypical concentration of gorgonian polyps in Verrucella sp. 20) Peronanthus sp4 with the gorgonian axis confined. 21) Sectioned specimens of Peronanthus sp4 with the confined gorgonian axis. 22) Specimen of Peronanthus sp4 showing two pedal rings with their scars.

Figs. 18-22.- 18) Áreas desprovistas de cenénquima en la especie Peronanthus sp3. 19) Concentraciones atípicas de pólipos de la gorgonia Verrucella sp. 20) Un ejemplar de la especie Peronanthus sp4 con el eje de la gorgonia confinado en su interior. 21) Sección del specimen de la especie Peronanthus sp4 con el eje de la gorgonia confinado en su interior. 22) Espécimen de Peronanthus sp4 mostrando dos anillos pedales con sus cicatrices. 
gorgonian substances trough the pedal ring can not be excluded totally, the particular positioning of some Peronanthus sp4 on the gorgonian branches (see Fig. 20-21) suggesting this possibility.

The image of Stephanauge annularis published by Fautin (2003), suggest that the pennatularian host is strangled. However, more material should be examined in order to ascertain this aspect.

\section{PARASITISM VERSUS OTHER ASSOCIATIONS}

Given the damage that RSA can cause to gorgonians, inquilinism cannot be applied to the association studied here. "Inquilinism is used to describe those associations in which one animal lives within another, doing the host little or no harm, but simply using it as a place of more or less permanent refuge" (Morton, 1989). Parasitism more adequately characterizes the relationship between RSA and their hosts. First, RSA are smaller than their hosts and cause damage in different ways (strangling polyps and coenenchyme, lateral crushing, interrupting the solenial communication) with the final effect of removing polyps and coenenchyme from the gorgonian axis. Second, the RSA species exhibit asexual reproduction, colonizing the hosts progressively. Third, it seems RSA are confined to one host throughout their whole life, or at least an important period of that. Fourth, the special attachment structure with extensive morphological transformations with respect to the general plan implies high dependence of RSA on their hosts.

Our current knowledge about RSA does not allow confirmation or rejection of preying upon gorgonians, or the absorption of substances from the gorgonian hosts, by ring sea anemones. Reaching the gorgonian axis is the final effect of colonization by RSA. By different means this is also obtained by certain zoantharian species that settle on live colonies of anthozoans with an organic axis (Ocaña et al., 1995; Ocaña \& Brito, 2004). Metabolic dependence is an essential criterion of a parasitic relationship (Morton, 1989). Although we cannot exactly establish the relationship of RSA'S on their hosts, we do not consider it appropriate to define a new association category in order to accommodate it. It is preferable to not restrict parasitism to the situation where food is obtained directly from the hosts. Thus an association where evident harm is done to one partner represents parasitim. In the case of RSA, reaching to the host axis by eliminating the live parts of the gorgonian (or pennatularian) can be understood as a long term metabolic dependence on the host.

\section{ACKNOWLEDGEMENTS}

Part of the material studied was collected during the cruises of the New Zealand Oceanographic Institute, now integrated in NIWA (National Institute of Water and Atmospheric Research). Special gratitude is due to Dennis Gordon, Head of the New Zealand Marine Biodiversity Programme, who made travelling around New Zealand's sea shores possible and encouraged the first author to study New Zealands soft hexacorals. He also made available some bibliography used in this study. Helmut Zibrowius sent the material from Reunion Island obtained during cruise MD 32 and provided observations and comments on these organisms. Yukimitsu Imahara kindly sent the material of Peronanthus sp3.

T.J.G.M. van Oyen prepared the histological slides and M. Slierings took care of the New Zealand collection in the RMNH. Special gratitude is due to Juan Carrasco for his very helpful advice regarding the images included here.

Marymegan Daly provided corrections and suggestions in relation to the present paper. O. Ocaña appreciated discussing with Verena Häussermann, Estefanía Rodriguez, Luciana Gusmao, Tina Molodtsova, Adorian Ardelean and Kensuke Yanagi during the $7^{\text {th }}$ ICCB. Special gratitude is due to Helmut Zibrowius and Verena Häussermann for their comments and valuable suggestions about this manuscript.

\section{References}

BAYER, F. M., 1961. The shallow-water Octocorallia of the West Indian Region. A manual for marine biologists. Studies on the fauna of Curaçao and other Caribbean islands, 12: 1-373.

BAYER, F. M. \& GRAsshoff, M., 1994. The genus group taxa of the family Ellisellidae, with clarification of the genera established by J.E. Gray. Senckenbergiana biologica, 74(1/2): 21-45.

Benham, W. B., 1928. On some Alcyonarians from New Zealand waters. Transactions and Proceedings of the New Zealand Institute, 59: 67-84.

Carlgren, O., 1934. Ceriantharia, Zoantharia and Actiniaria. Report on the Scientific results of the "Michael Sars" North Atlantic Deep-Sea Expedition 1910, 5(6): 27 pp.

Carlgren, O., 1936. Some west American sea anemones. Journal of the Washington Academy of Sciences, 26(1): 16-23.

CArlgren, O., 1949. A survey of the Ptychodactiaria, Corallimorpharia and Actiniaria. Kungliga Svenska Vetenskapsakademiens Handlingar, Fjärde Serien, 1(1): 1-121.

Dayton, P. K., England, K. W. \& Robson E. A., 1995. An unusual sea anemone, Dactylanthus antarcticus (Clubb, 1908) (Order Ptychodactiaria), on gorgonians in Chilean fjords. In: den Hartog, J. C., van Ofwegen, L. P. \& van der Spoel, S. (eds). Proceedings of the $6^{\text {th }}$ International Conference on Coelenterata Biology, The Leeuwenhorst, Noordwijkerhout: 135-142. 
Duchassaing, P. \& Michelotti, J., 1860. Mémoire sur les coralliaires des Antilles. Memorie della Reale Accademia delle Scienze di Torino, (2), 19: 279-365.

FAutin, D. G., 2003. Hexacorals of the World: Sea anemones, Corals and their allies.

http://hercules.kgs.ku.edu/hexacoral/anemone2/imagedetail.cfm?

GRAY, J.E. 1860. Description of some new genera of lithophytes or stony zoophytes. Proceedings of the Zoological Society of London, 1859: 479-486.

GrAVIER, C., 1922. Hexactinidés provenant des campagnes des yachts Hirondelle I et II et Princesse Alice I et II (1888-1913). Résultats des Campagnes Scientifiques accomplies sur son yatch, par Albert $1^{e r}, 63: 1-104$.

HiLEs, I., 1899. The gorgonacea collected by Dr. Willey. Zoological results based on material from New Britain, New Guinea, Loyalty Islands and elsewhere, collected during the years 1895, 1896 and 1897, by Arthur Willey, part 2: 195-206.

KocH, G. von, 1878. Mitteilungen über Coelenteraten. Gephyra dohrnii. Morphologisches Jahrbuch, IV: 74-86.

KüKenthal, W., 1924. Gorgonaria. Das Tierreich, 47: ixxviii $+1-478$

Milne-Edwards, A. \& Haime, J., 1857. Histoire naturelle des Coralliaires ou polypes proprement dits. Tome troisiéme: suite de la section des Madréporaires apores. Roret. Paris. 560 pp.

Moroff, T., 1902. Studien über octocorallien. 1. Ueber die Pennatulaceen des Münchener Museums- II. Ueber einige neue gorgonaceen aus Japan. Zoologische Jahrbücher. Abteilung für Systematik, Geographie und Biologie der Tiere, 17: 363-410.

Morton, B., 1989. Partnerships in the sea: Hong Kong's marine symbioses. Hong Kong University Press and E. J. Brill. Hong Kong. 124 pp.

OCAÑA, O., 1994. Actiniaria y Corallimorpharia de la Macaronesia Central: Canarias y Madeira. Tesis Doctoral. Universidad de La Laguna. 2 volúmenes, $484 \mathrm{pp}$.

OCAÑA, O. \& BRITO, A., 2004. A review of Gerardiidae (Anthozoa: Zoantharia) from the Macaronesian Islands and the Mediterranean Sea with the description of a new species. Revista de la Academia Canaria de Ciencias, 3-4: 159-189.
Ocaña, O., Brito, A., Nuñez, J. \& Bacallado, J. J., 1995. Redescripción del zoantario (Cnidaria: Anthozoa) Gerardia savaglia (Bertoloni, 1819). Vieraea, 24: 153-164.

Отто, A. W., 1823. Beschreibung einiger neuen Mollusken und Zoophyten. Nova Acta Academiae Caesareae Leopoldino-Carolinae Germanicae Naturae Curiosorum, 11(2): 273-314.

RIEMANN-ZÜRNECK, K., 1998: How sessile are sea anemones? A review of free-living forms in the Actiniaria (Cnidaria: Anthozoa). Marine Ecology, 19(4): 247-261.

RIEMANN-ZÜRNECK, K \& GRIfFITHS, C. L., 1999. Korsaranthus natalensis (Carlgren, 1938) nov. comb. (Cnidaria: Actiniaria) a mobile sea anemone attacking octocorals. South African Journal of Zoology, 34(4): 190-196.

Toeplitz, C., 1929. Die Gorgonarien Westindiens. Kap. 7, Die Famile Gorgonellidae, zugleich eine Revision. Zoologische Jahrbücher Supplement, 16(2): 235376.

Verrill, A.E., 1879. Notice of Recent Additions to the Marine Invertebrata, of the Northeastern Coast of America, with Descriptions of New Genera and Species and Critical Remarks on Others. Part IAnnelida, Gephyraea, Nemertina, Nematoda, Polyzoa, Tunic. Proceedings of the United States National Museum, 2: 165-226.

Wright, E. P., 1869. On a new genus of Gorgonidae from Portugal. Annals and Magazine of Natural History, (4), 3: 23-26, 3 text figs. 